\title{
Engineering of Bacillus megaterium for improving PHA production from glycerol
}

\author{
Javier Ricardo Gómez Cardozo ${ }^{a}$, Rodrigo Velasco Bucheli ${ }^{b}$, Carlos del Cerro Sánchez ${ }^{c}$, Isabel de la Mata \\ Riesco ${ }^{\mathrm{d}}$, Amanda Lucía Mora Martínez ${ }^{\mathrm{e}^{*}}$ \\ ${ }^{a}$ Facultad de Ciencias, Universidad Nacional de Colombia, Medellin, Colombia \\ ${ }^{b}$ Enzyme Development, Roche Diagnostics GmbH, Penzberg, Germany \\ 'Microbial and Plant Biotechnology Department, Centro de Investigaciones Biológicas CIB-CSIC, Madrid, Spain \\ ${ }^{d}$ Departamento de Bioquímica y Biología Molecular I, Facultad de Biología, Universidad Complutense de Madrid, Madrid, Spain \\ ${ }^{e}$ Escuela de Quimica, Facultad de Ciencias, Universidad Nacional de Colombia, Medellin, Colombia
}

Received 9th May 2019 / Accepted 24th June 2019

\begin{abstract}
There are a few PHA-producer bacteria that can uptake glycerol to produce this biopolymer. Among them, Bacillus megaterium LVN01 has demonstrated to be able to grow up using glycerol as a carbon source. Glycerol dehydrogenase (GD) plays a key role in the synthesis of PHA from glycerol. In this study, the improvement of glycerol uptake by a recombinant strain of B. megaterium carrying pHT01-bmgd was evaluated in order to enhance PHA production. The biomass and PHA production were evaluated and compared to wild-type. It was determined that the PHA produced by both strains was PHB and the highest improvement in PHB yield was $226 \%$ at $30 \mathrm{~h}$.
\end{abstract}

Keywords: Bacillus megaterium, glycerol, glycerol dehydrogenase, polyhydroxyalkanoates

\section{INTRODUCTION}

During the last decades, biofuels have been considered as important alternatives to stop global warming, however, this endeavor contrasts with waste glycerol production, which has emerged as an important contaminant byproduct (Kalia et al., 2016; Mohapatra et al., 2017).

A few wild-type bacteria are able to synthesize PHA from glycerol as the sole carbon and energy sources, such as Bacillus (Okwuobi and Ogunjobi, 2013), Burkholderia (Rodríguez-Contreras et al., 2015), Cupriavidus (Campos et al., 2014), Halomonas (Kawata and Aiba, 2010), Novosphingobium (Teeka et al., 2012), Pseudomonas (Pappalardo et al., 2014; Ashby et al., 2015) and Zobellella (Ibrahim and Steinbüchel, 2010).
Polyhydroxyalkanoates are macromolecules synthesized by many bacteria, and it is accumulated as intracellular granules to levels as high as $90 \%$ of cell dry weight (Reddy et al., 2003). It is stored in those microorganisms under conditions of nutrient stress in the presence of an excess carbon source (Reddy et al., 2009; Bhuwal et al., 2014). It has been demonstrated that Bacillus megaterium is able to produce different kinds of PHA from many feedstocks (including glycerol), such as poly(3HB-co-3HV) and PHB (Moreno et al., 2015; Porras et al., 2017).

Glycerol is converted into PHA by an oxidative pathway via the $\mathrm{NAD}^{+}$-dependent enzyme glycerol dehydrogenase that catalyzes the

\footnotetext{
*Author for correspondence: Amanda Lucía Mora Martínez, Escuela de Química, Facultad de Ciencias, Universidad Nacional de Colombia, Medellin, Colombia. Email - almora@unal.edu.co
} 
conversion of glycerol to dihydroxyacetone. The glycolytic enzyme dihydroxyacetone kinase phosphorylates this ketone, which is then incorporated into the glycolysis pathway, and eventually transformed to pyruvate (da Silva et al., 2009; Zhu et al., 2013). The pyruvate dehydrogenase transforms pyruvate to acetylCoA. Then two molecules of acetyl-CoA are condensed by $\beta$-ketothiolase (PhaA) into acetoacetyl-CoA. The acetoacetyl-CoA reductase $(\mathrm{PhaB})$ reduces acetoacetyl-CoA to (R)-3hydroxyalkyl-CoA. Finally, PHA synthase (PhaC) polymerize 3-hydroxyalkyl-CoA to PHA (Figure S1).

Bacillus megaterium is a well-known PHAproducer bacterium able to convert different carbon sources into short-chain-length (scl)polymers (e.g. poly(3-hydroxybutyrate)) or sclcopolymers (e.g. poly(hydroxybutyrate-cohydroxyvalerate)) (Możejko-Ciesielska and Kiewisz, 2016). The classical approach to improve the PHA production by conventional fermentation strategies is not good enough in order to achieve yields suitable for industrial purposes. For instance, modifications of the $\mathrm{C} / \mathrm{N}$ ratio or dissolved oxygen could induce forming endospore, which reduces the yield of PHA production (Koller et al., 2016).

Nowadays, metabolic engineering is one of the most powerful tools among the strategies implemented to increase yield in biotechnological processes, and in this case, it is implemented either to enhance the use of the substrates (Povolo et al., 2010) or to avoid the degradation of the PHA, once it is synthesized (Povolo et al., 2015).

The advantages of using a PHA producer such as $B$. megaterium are an absence of toxic lipopolysaccharides (biologically safe) (Stewart et al., 2006), and high PHA yield and broad spectra of synthesized biopolymers from many sources (Kumar et al., 2013). Likewise, metabolic manipulation in B. megaterium has been reported, such as engineered recombinant strains with easy PHA recovery by self-disruptive mechanism (Hori et al., 2002), tailored PHA producers (Singh et al., 2015), or obtaining functional intracellular materials (Grage et al., 2017), among others.

In this study, we report the obtaining of a recombinant clone $B$. megaterium $B m G D$ capable to accumulate PHA and grow up faster than the wild-type, using glycerol as the carbon source. This recombinant strain is suitable for industrial application since it is able to use a cheap and contaminant carbon source, while it displays an improved PHA-production in a short period of time.

\section{MATERIALS AND METHOD}

\section{Bacterial strains, plasmids and growth} conditions. Bacillus megaterium LVN01, Colección Española de Cultivos Tipo (CECT) 9345 (Sánchez et al., 2012), Escherichia coli DH5 $\alpha\left(\mathrm{F}^{-}\right.$ Ф80lacZ $\Delta$ M15 $\Delta$ (lacZYA-argF) U169 recA1 endA1 bsdR17 $\left(\mathrm{r}_{\mathrm{K}}^{-}, \mathrm{m}_{\mathrm{K}}^{+}\right)$phoA supE44 $\lambda^{-}$thi-1 gyrA96 relA1), and the plasmid pHT01 (Amp ${ }^{\mathrm{r}}, \mathrm{Cm}^{\mathrm{r}}$, or ColE1) were used in this study. Bacillus megaterium LVN01 was used as the bacterial host and for expression. Escherichia coli $\mathrm{DH} 5 \alpha$ was used as the host for plasmids and constructions. The vector pHT01 (MoBiTec GmbH) was used in all transformation experiments. Bacillus megaterium LVN01 and E. coli DH5 $\alpha$ cells were grown in LB medium consisting of $1 \%$ bacto-tryptone $0.5 \%$ yeast extract and $1 \% \mathrm{NaCl}$, and incubated at $30^{\circ} \mathrm{C}$ and $37^{\circ} \mathrm{C}$, respectively. Solid media contained $1.75 \%$ (w/v) agar. Transformants of B. megaterium obtained by electroporation, and from E. coli obtained by heat-shock were resuspended in LB medium. Antibiotics were supplemented as required at the following concentration: for $B$. megaterium BmGD chloramphenicol $5 \mu \mathrm{g} \mathrm{mL} \mathrm{L}^{-1}$ and for recombinant clones of E. coli ampicillin $100 \mu \mathrm{g}$ $\mathrm{mL}^{-1}$.

Construction of recombinant $B$. megaterium $\boldsymbol{L} \boldsymbol{V N} 01$ strains. Plasmids were isolated using the PureLink $^{\circledR}$ Quick Plasmid Miniprep Kit (Life Technologies). The DNA was analyzed by electrophoresis in $0.8 \%(\mathrm{w} / \mathrm{v})$ agarose gel slices mixing with GelRed Nucleic Acid Gel Stain (Biotium) and GeneRuler ${ }^{\mathrm{TM}} 1 \mathrm{~kb}$ Plus DNA Ladder (Thermo Scientific) used as the marker. All DNA fragments were isolated from agarose gel using the GFX PCR DNA and Gel Band Purification Kit (GE healthcare). Restriction enzymes (BamHI and SmaI) and T4 DNA ligase (New England BioLabs) were used according to instructions provided by the supplier. The bmgd 
gene (1.13 kbp) PCR product was amplified from the chromosomal DNA of B. megaterium LVN01 (GenBank: QJGY00000000.1). The PCR product was subsequently purified and digested by restriction enzymes. Thereafter, bmgd was cloned in pHT01 $(7.96 \mathrm{~kb})$. The ligation product was transformed in E. coli DH5 $\alpha$ for amplification. The mutant plasmid was isolated from E. coli transformants, and it was finally transformed in $B$. megaterium LVN01 by electroporation.

The PCR amplification of $B$. megaterium glycerol dehydrogenase (bmgd) gene was performed using a PCR program in the MJ Mini Gradient Thermal Cycler (BioRad). Denaturation at $95^{\circ} \mathrm{C}$ for $5 \mathrm{~min}$, followed by 30 cycles of denaturation at $95^{\circ} \mathrm{C}$ for $1 \mathrm{~min}$, annealing at $53.6^{\circ} \mathrm{C}$ for $1 \mathrm{~min}$ and elongation at $72^{\circ} \mathrm{C}$ for 2.5 min. A final elongation at $72^{\circ} \mathrm{C}$ for 15 minutes was carried out.

The primers used were BmGD1 5'TCCCCCGGGGGATTATATTAACCTCTTC3', BmGD2 5'CGGGATCCCGATGAGGAAAG CAT'T'TATTAG-3', BmGD-Nt 5'-CATCGAAA GCACCCTCTGGT-3', and BmGD-Ct 5'-GTGG ATTAGCTGGCGCACAT-3'.

$\boldsymbol{P H B}$ production. For PHB analysis, Bacillus megaterium strains were inoculated in Minimal Salt Medium (MSM), which contains $20.0 \mathrm{~g} \mathrm{~L} \mathrm{~L}^{-1}$ glycerol, $1.0 \mathrm{~g} \mathrm{~L}^{-1}$ yeast extract, $1.5 \mathrm{~g} \mathrm{~L}^{-1} \mathrm{KH}_{2} \mathrm{PO}_{4}$, $3.6 \mathrm{~g} \mathrm{~L}^{-1} \mathrm{Na}_{2} \mathrm{HPO}_{4}, 0.8 \mathrm{~g} \mathrm{~L}^{-1}\left(\mathrm{NH}_{4}\right)_{2} \mathrm{SO}_{4}, 0.2 \mathrm{~g} \mathrm{~L}^{-1}$ $\mathrm{MgSO}_{4} \cdot 7 \mathrm{H}_{2} \mathrm{O}$, and $1.0 \mathrm{~mL}$ of trace element solution. The trace element solution contained: $10.0 \mathrm{~g} \mathrm{~L}^{-1} \mathrm{FeSO}_{4} \cdot 7 \mathrm{H}_{2} \mathrm{O}, 2.25 \mathrm{~g} \mathrm{~L}^{-1} \mathrm{ZnSO}_{4} \cdot 7 \mathrm{H}_{2} \mathrm{O}$, $1.0 \mathrm{~g} \mathrm{~L}^{-1} \mathrm{CuSO}_{4} \cdot 5 \mathrm{H}_{2} \mathrm{O}, 0.5 \mathrm{~g} \mathrm{~L}^{-1} \mathrm{MgSO}_{4} \cdot 5 \mathrm{H}_{2} \mathrm{O}, 2.0$ $\mathrm{g} \mathrm{L}^{-1} \mathrm{CaCl}_{2} \cdot 2 \mathrm{H}_{2} \mathrm{O}, 0.23 \mathrm{~g} \mathrm{~L}^{-1} \mathrm{Na}_{2} \mathrm{~B}_{4} \mathrm{O}_{7} \cdot 10 \mathrm{H}_{2} \mathrm{O}, 0.1$ $\mathrm{g} \mathrm{L}^{-1}\left(\mathrm{NH}_{4}\right)_{6} \mathrm{Mo}_{7} \mathrm{O}_{24}$ and $10.0 \mathrm{~mL} \mathrm{35.0 \%} \mathrm{HCl}$ (Kim et al., 1994). Chloramphenicol $\left(5.0 \mu \mathrm{g} \mathrm{mL} \mathrm{m}^{-1}\right)$ was supplemented when necessary. When the $\mathrm{OD}_{600}$ of the culture broth was equal to 1.0, the expression of $B m G D$ in the bacterium was induced with $1.0 \mathrm{mM}$ IPTG and further incubated at $30^{\circ} \mathrm{C}$. That moment was considered as $\mathrm{t}_{0}=0 \mathrm{~h}$, and at different time were collected samples for analysis.

\section{Analytical procedures. \\ Determination of biomass and $\mathrm{PH} A$ extraction.}

Samples of $50 \mathrm{~mL}$ of culture broth were taken and centrifuged in pre-weighed plastic screw cap tube for $15 \mathrm{~min}$ at $8000 \times g$ at $4^{\circ} \mathrm{C}$. Pellets were frozen and lyophilized and gravimetric difference against empty tube was calculated. PHA extraction was carried out in centrifuged cells by the method of Jacquel et al. (Jacquel et al., 2008) with some modifications. For each $20 \mathrm{mg}$ of biomass $1 \mathrm{~mL}$ of chloroform and $1 \mathrm{~mL}$ of hypochlorite $(5 \% \mathrm{v} / \mathrm{v})$ were used, the mixture was incubated at $35^{\circ} \mathrm{C}$ for $2 \mathrm{~h}$. The mixture was centrifuged $(10000 \mathrm{xg}$, for 10 min at $20^{\circ} \mathrm{C}$ ), the supernatant was discarded, and the dissolved polymer in chloroform was recovered by solvent evaporation.

\section{PHA Quantification.}

The PHA quantification was carried out by crotonic acid method with some modifications. For each $0.1 \mathrm{mg}$ of PHA recovered from biomass, $1 \mathrm{~mL}$ of $98 \%$ sulfuric acid was added and heated at $100^{\circ} \mathrm{C}$ for $10 \mathrm{~min}$. The absorbance was measured at $235 \mathrm{~nm}$ in a UV-VIS spectrophotometer. Poly(3-hydroxybutyric acid) (Sigma-Aldrich) was used for the standard curve. The PHA yield was calculated using a calibration curve (Fig. S2), and the improvement in the production was calculated as follows:

$$
\begin{aligned}
& \text { PHA yield }\left(\mathrm{mg} \mathrm{L}^{-1}\right)=\left(\mathrm{A}_{235}-0.0604\right) / 0.1885 \\
& \text { Improvement }(\%)=\left[\mathrm{PHA} \text { in BmGD }\left(\mathrm{mg} \mathrm{L}^{-1}\right) / \mathrm{PHA} \text { in } \mathrm{LVN01}\left(\mathrm{mg} \mathrm{L}^{-1}\right)\right]^{* 100 \%}
\end{aligned}
$$

Fourier Transform-Infrared Spectroscopy (FT-IR). The polymer extracted from B. megaterium LVN01 and $B$. megaterium $B m G D$, as well as the commercial PHB (Sigma-Aldrich), were analyzed by FT-IR. Spectra were recorded using a Spectrum Two FT-IR spectrometer (PerkinElmer). For each measurement, 32 scans were acquired and averaged in the range of 4000 to $400 \mathrm{~cm}^{-1}$ with a spectral resolution of $4 \mathrm{~cm}^{-1}$.

Nuclear Magnetic Resonance (NMR).

In order to know the chemical structure of the PHA obtained from B. megaterium $B m \mathrm{GD}$, and compare this compound with the commercial 
PHB, an analysis was carried out by onedimensional nuclear magnetic resonance of proton $\left({ }^{1} \mathrm{H}\right)$ and carbon $\left({ }^{13} \mathrm{C}\right)$. The spectra were taken on a Bruker 300 NMR spectrometer at 300 $\mathrm{MHz}$, using tetramethylsilane (TMS) as the internal standard. For each measurement, 5 to 10 mg of sample was taken and dissolved in $\mathrm{CDCl}_{3}$.

\section{RESULTS}

\section{Bacillus megaterium LVN01 genome. Bacillus} megaterium LVN01 is a Gram-positive bacterium able to produce PHA. Its draft genome was obtained from a shotgun library constructed and sequenced using Illumina Hiseq 2000 Instruments (Macrogen Inc., Korea). The genome comprises $5.22 \mathrm{Mbp}$ with $37.8 \% \mathrm{G}+\mathrm{C}$ content, obtaining 4169 contigs from $1.5 \times 10^{7}$ reads by Newbler 2.5.3. Twenty-one RNA genes ( 4 rRNA and 17 tRNA) and 4846 coding sequences (CDS) were detected by RAST (Aziz et al., 2008). Regarding CDSs, 1758 were assigned with putative functions and 1715 were classified as hypothetical proteins, including at least 22 enzymes that could play important roles in the biological generation of PHA (data not shown). According to antiSMASH (Medema et al., 2011), this genome contains at least 6 clusters associated with siderophores, terpenes, polyketide synthases (T3PKS) and phosphonates biosynthesis. Despite the average value of cluster in $B$. megaterium is 11 , it is important to point out that the estimation is 6 , according to the assessment of complete genomes of this strain (Liu et al., 2011; Eppinger et al., 2011; Johnson et al., 2015). Table S1 shows the genomic features of B. megaterium LVN01 in comparison to different strains of $B$. megaterium reported in public databases (last update: 29-11-2018).

Furthermore, genome analysis of B. megaterium LVN01 using RAST detected 472 subsystems related in the metabolism of carbohydrates, 32 directly related with glycerol metabolism and 149 with fatty acids and lipids, among others (Figure S3).

As was expected, the comparison of its $16 \mathrm{~S}$ rRNA gene-sequence with other conserved sequences available in NCBI database indicated that this strain is taxonomically close to other $B$. megaterium strains (Figure S4). Similarly, it was possible to detect in B. megaterium LVN01 draft genome similar genes that belong to this strain, such as spore coat $(\operatorname{Cot} B, \operatorname{Cot} D, \operatorname{Cot} E, \operatorname{Cot} F, \operatorname{Cot} H$, $\operatorname{Cot} A A, \operatorname{CotJB}, \operatorname{Cot} C, \operatorname{Cot} P, \operatorname{Cot} R, \operatorname{Cot} S, \operatorname{Cot} X$, CoxA, GerQ, SafA, YaaH, YmaG, and YxeE), genes involved in gas vesicle biosynthesis $g \nu$, operon I (gupBRFGLSKJ) and operon II (grpAPQBRNFGLSKJTU) (Eppinger et al., 2011).

Glycerol dehydrogenase-encoding gene (bmgd) from B. megaterium LVN01. The sequence of $b m g d$-encoding gene was detected and analyzed by BLAST from NCBI through comparison with glycerol dehydrogenases (GD) from other Bacillus megaterium (Figure S5). The bmgd-encoding gene has a size of 1134 bp, GCcontent $37.9 \%$, and it is located within the contig 167 (GenBank: QJGY01000167.1). Further analysis of $B$. megaterium LVN01 glycerol dehydrogenase ( $B m \mathrm{GD})$ sequence displays that it has $97 \%$ of identity with the GD from $B$. megaterium WSH-002 (Liu et al., 2011) and high identity (99\%) with the GD from B. megaterium QM B1551 (Eppinger et al., 2011) and B. megaterium JX285 (Johnson et al., 2015).

In particular, $B m G D$ has 377 residues, a molecular mass of $40.15 \mathrm{kDa}$, and a predicted isoelectric point of 4.72. The secondary structure of $B m$ GD predicted by PredictProtein (Yachdav et al., 2014) displays $52.52 \%$ of helix, $9.02 \%$ of strand and $38.46 \%$ of loops.

Regarding its catalytic pocket, it has been reported the crystal structure of Bacillus stearothermophilus glycerol dehydrogenase (GlyDH), and it has D39, S127, L129 and Y133 as residues in the binding site for $\mathrm{NAD}^{+}$, and D123, D173, H256, H274 as amino acids in the glycerol binding site (Ruzheinikov et al., 2001). The protein alignment with $B m G D$ shows that its binding site for $\mathrm{NAD}^{+}$could be formed by $\mathrm{D} 40$, S123, S125, and Y129, whereas D119, D169, $\mathrm{H} 264$, and H281 are part of its glycerol binding site (Figure S6).

The bmgd gene was amplified and cloned in pHT01 plasmid between SmaI and BamHI restriction sites. This shuttle vector was employed to obtain the recombinant strain $B$. megaterium $B m \mathrm{GD}$, which overexpress $B m \mathrm{GD}$. The mutant plasmid was corroborated by PCR and agarose gel, and the recombinant strain by colony PCR. 
The $B m \mathrm{GD}$ expression band was also visualized by SDS-PAGE (Figure S7).

\section{Microbial growth using glycerol as carbon} and energy source. The growth and PHA yield of B. megaterium LVN01 and B. megaterium BmGD were compared using glycerol as the carbon source. The dry-weight comparison between both strains using glycerol highlights that the recombinant strain is producing more biomass in less time than wild-type (Figure 1). Similarly, the PHA content in the recombinant clone displays a clear improvement of the PHA yield in comparison to the wild-type during the evaluation under the operating conditions (Figure 2). The PHA yield reached the highest improvement $(226 \%)$ between $24 \mathrm{~h}$ and $30 \mathrm{~h}$.

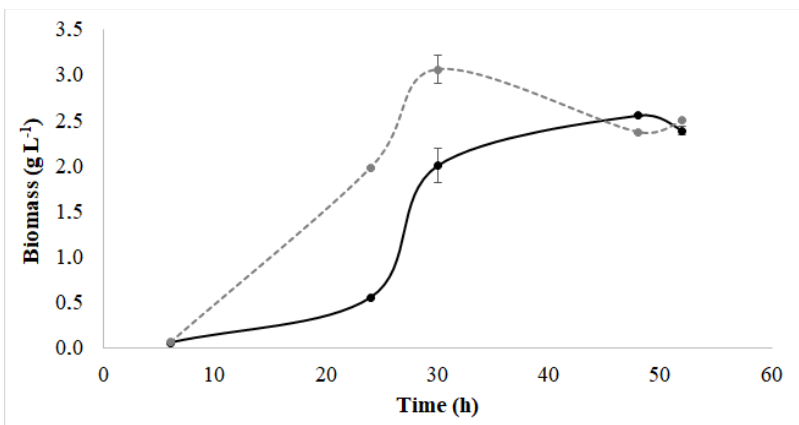

Figure 1. Dry weight cell of $B$. megaterium LVN01 (solid line) and B. megaterium BmGD (dotted line) in waste glycerol $\left(\mathrm{C} / \mathrm{N}\right.$ ratio $44.9 \mathrm{~mol} \mathrm{~mol}^{-1} ; 30^{\circ} \mathrm{C}$, $\mathrm{pH}$ 7.0).

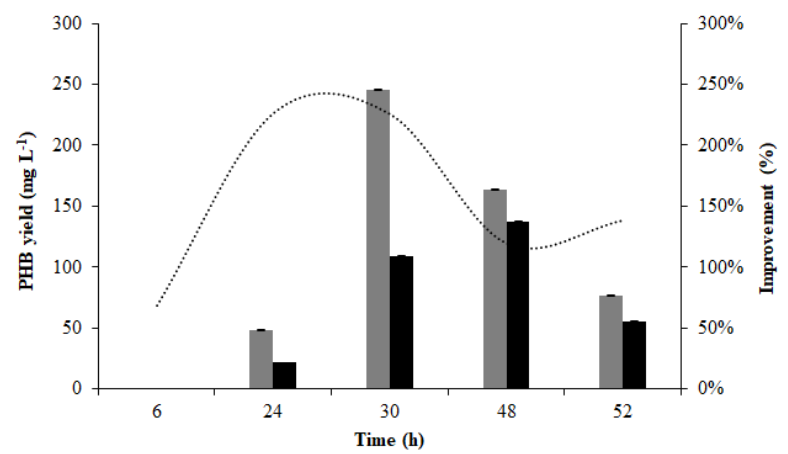

Figure 2. Poly (3-hydroxybutyric acid) yield of $B$. megaterium LVN01 (black) and $B$. megaterium $B m \mathrm{GD}$ (gray) in glycerol (C/ $\mathrm{N}$ ratio $44.9 \mathrm{~mol} \mathrm{~mol}^{-}$ ${ }^{1} ; 30^{\circ} \mathrm{C}, \mathrm{pH} 7.0$ ). The dotted line represents the improvement of the process at different times.

A similar approach was carried out regarding the PHA content (Table S2). This analysis highlighted that the recombinant clone is not only able to grow fast (Figure 1) and obtain higher PHA yield (Figure 2), but it also contains a higher amount of PHA into the cells in comparison to the wild-type (Figure 3). This improvement is more evident after $30 \mathrm{~h}$ of incubation, and it remains higher thereafter.



Figure 3. Poly (3-hydroxybutyric acid) content in B. megaterium LVN01 (black) and B. megaterium $B m$ GD (gray) in glycerol (C/N ratio $44.9 \mathrm{~mol} \mathrm{~mol}^{-}$ $\left.{ }^{1} ; 30^{\circ} \mathrm{C}, \mathrm{pH} 7.0\right)$. The dotted line represents the improvement in the accumulation at different times.

Fourier transform infrared spectra for PHA from $B$. megaterium $L V N 01$. Fourier transform infrared (FT-IR) spectra from commercial PHB and PHA produced by both $B$. megaterium strains from glycerol were compared (Figure 4). The absorption peaks at $1720 \mathrm{~cm}^{-1}$ and $1280 \mathrm{~cm}^{-1}$, indicate the ester carbonyl group $(\mathrm{C}=\mathrm{O})$ and $(\mathrm{C}$ $\mathrm{O})$ ester stretching, respectively. The peaks between $1450 \mathrm{~cm}^{-1}$ and $800 \mathrm{~cm}^{-1}$ are due to methyl $\left(\mathrm{CH}_{3}\right)$ and methylene $\left(\mathrm{CH}_{2}\right)$ deformations and ester stretching $(\mathrm{C}-\mathrm{O})$. In this case, it is possible to observe some characteristics bands for PHB, such as the bands at $1228 \mathrm{~cm}^{-1}, 1380 \mathrm{~cm}^{-1}$, and $1180 \mathrm{~cm}^{-1}$ are $\mathrm{CH}_{2}, \mathrm{CH}_{3}$, and $\mathrm{C}-\mathrm{O}-\mathrm{C}$ groups, respectively (Sathiyanarayanan et al., 2013).

Nuclear magnetic resonance (NMR). The analysis of the NMR spectra corresponding to ${ }^{13} \mathrm{C}$ and ${ }^{1} \mathrm{H}$ made it possible to elucidate the structure of the biopolymer produced. Figure S8 (I) shows the chemical shift of the signals corresponding to different types of carbon atoms in the commercial PHB structure $(\mathrm{C}=\mathrm{O} \delta=169.20 \mathrm{ppm}, \mathrm{CH} \delta=$ 67.65, $\left.\mathrm{CH}_{2} \delta=40.81 \mathrm{ppm}, \mathrm{CH}_{3} \delta=19.80 \mathrm{ppm}\right)$, which are compared with the PHA spectrum produced by $B$. megaterium LVN01 is confirmed to be PHB (Figure S8 (II)). 
These results are comparable with those reported in other studies for the PHB produced by B. megaterium strains (Doi et al., 1986; López et al., 2012; Baikar et al., 2017; Pradhan et al., 2018).

On the other hand, Figure S9 shows the ${ }^{1} \mathrm{H}$ NMR spectra of the commercial PHB and the PHB obtained from B. megaterium LVN01. The signals at $\delta=1.30 \mathrm{ppm}(\mathrm{c})$ indicate the presence of the methyl $\left(\mathrm{CH}_{3}\right)$ group, $\delta=2.50-2.64 \mathrm{ppm}$ (b) for the methylene $\left(\mathrm{CH}_{2}\right)$ group and $\delta=5.28$ ppm (a) for the methino group $(\mathrm{CH})$. These values are similar to those reported for the PHB produced by B. megaterium strains (Balakrishna Pillai et al., 2016; Baikar et al., 2017; Pradhan et al., 2018).

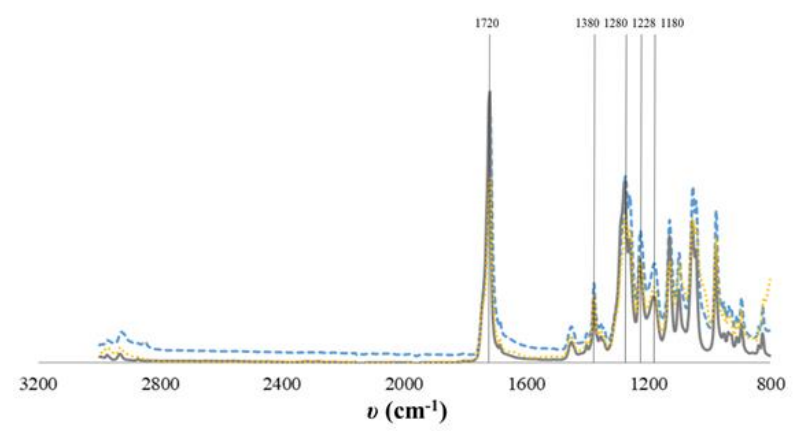

Figure 4. FT-IR spectra for PHB commercial, and PHB produced by B. megaterium LVN01 and B. megaterium $\mathrm{Bm} \mathrm{GD}$ from glycerol. $(-) \mathrm{PHB}$ commercial (Sigma-Aldrich), (…) PHB from $B$. megaterium LVN01, and (- -) PHB from $B$. megaterium $\mathrm{Bm} \mathrm{GD}$.

\section{DISCUSSION}

The phylogenetic analyses of $16 \mathrm{~S}$ rRNA genesequence from B. megaterium LVN01 showed that this strain belongs to Bacillus megaterium. It was confirmed by further analyses based on the comparison of different genes that only own $B$. megaterium strains according to Eppinger and coworkers (Eppinger et al., 2011). For example, genes involved in spore coat forming, gas vesicle biosynthesis as well as the gene responsible for the large size of the cell (fts Z). All of them were detected in B. megaterium LVN01 draft genome.

Despite the potentiality of $B$. megaterium for producing PHB from many carbon sources, only a few recombinant clones displaying better performance have been obtained (Hori et al., 2002; Gerber et al., 2015; Grage et al., 2017).

The identification and cloning of the $b m \mathrm{gd}-$ encoding gene allowed the obtaining of $B$. megaterium $B m \mathrm{GD}$. It is important to highlight that the sequence of $B m \mathrm{GD}$ is highly conserved since it has more than $94 \%$ of identity with all glycerol dehydrogenases reported in B. megaterium strains (Figure S4).

Two different pathways in microorganisms for PHA production from glycerol have been described; an anaerobic process and an aerobic one. Under anaerobic conditions, there are enzymes such as glycerol dehydratase (GDh) (EC 4.2.1.30) and propanal dehydrogenase (PD) (EC 1.2.1.87) that were identified in Klebsiella and Salmonella strains, respectively (Meng et al., 2014). In contrast, the aerobic process involves $\mathrm{NAD}^{+}$dependent glycerol phosphate dehydrogenase (EC 1.1.99.5) and a glycerol kinase (EC 2.7.1.30), and they have been reported in $B$. subtilis (Lindgren and Rutberg, 1974). As was expected, B. megaterium lacks glycerol dehydratase. Instead, the strain uptakes glycerol through glycerol dehydrogenase - BmGD (EC 1.1.1.6) and ATPdependent dihydroxyacetone kinase (EC 2.7.1.29), and finally, it is incorporated in the glycolysis pathway to produce PHA (Figure S1).

Glycerol dehydrogenase is a key enzyme to convert glycerol into PHA by an oxidative pathway. According to the performance of this enzyme, the process to obtain PHA could be successfully achieved. Therefore, the role of this enzyme also could be considered as a bottleneck in this endeavor. This enzyme is an intracellular $\mathrm{NAD}^{+}$-dependent oxidoreductase present in the glycerol uptake pathway of many microorganisms, and it has been reported as strict dependent on zinc for activity (Ruzheinikov et al., 2001). As was expected, no signal peptide was detected in the sequence, which means that this enzyme is involved in an intracellular catalytic step. Glycerol dehydrogenase catalyzes the oxidation of glycerol to dihydroxyacetone (1,3-dihydroxypropanone) with the reduction of $\mathrm{NAD}^{+}$to NADH.

In this study, we evaluated the feasibility to obtain a suitable $B$. megaterium recombinant strain that could overexpress $B m G D$ in order to raise the substrate concentration available inside the cells. Simultaneously, high PHA production was desirable. Bacillus megaterium BmGD was able to 
grow up using glycerol as the only substrate. It grew up faster than the wild-type under the same operating conditions. Bacillus megaterium BmGD achieved its maximum biomass production at 30 $\mathrm{h}$ whereas the wild-type required $48 \mathrm{~h}$. Likewise, it is notorious the improvement of the yield of PHA. Similarly, the recombinant clone contains a higher amount of PHA into the cells in comparison to the wild-type after $30 \mathrm{~h}$ of incubation. This performance makes this recombinant microorganism suitable for industrial applications.

A comparison of both strains point out that the wild-type needs $48 \mathrm{~h}$ for obtaining the maximum yield and PHB content, and thereafter, it reduces drastically both parameters, whereas the recombinant clone displays improvement sooner, it achieves its maximum performance at $30 \mathrm{~h}$ and conserves a high PHB content until $48 \mathrm{~h}$.

Glycerol dehydrogenase and its connection with the PHA metabolism have been studied in detail (Lopar et al., 2014; Meng et al., 2014; Magdouli et al., 2015) Although there are reports of recombinants clones with better glycerol tolerance and improved PHA production (Nikel et al., 2008; Kocharin et al., 2012), up to now, there was no evidence that the overexpression of this enzyme produces recombinant clones with faster growth, higher PHA accumulation as well as higher yield.

A comparison by FTIR and NMR confirmed that both $B$. megaterium strains (wild-type and recombinant) were able to produce PHB from glycerol. The comparison considered commercial PHB, and PHB obtained from the wild-type strain incubated under optimal operating conditions. Further studies will clarify if the optimal operating conditions were altered in the recombinant strain, in terms of biomass and PHA production.

Finally, it is necessary evaluating if further enzymes involve in glycerol uptake in B. megaterium can be considered also as a bottleneck. Similarly, a metabolic engineering approach can help us to figure out the real role of glycerol dehydrogenase in PHA biosynthesis. Nevertheless, with the evidence in this study, it is possible to propose that the performance and expression of this enzyme could be considered as a bottleneck in PHA production from glycerol by this strain. It is evident that thanks to this enzyme, it was possible to obtain an engineered strain able to accumulate a higher amount of $\mathrm{PHB}$, faster and with a higher yield.

\section{ACKNOWLEDGMENTS}

This study was funded by Departamento Administrativo de Ciencia, Tecnologi $\square$ a e Innovacio $\square \mathrm{n}$ de Colombia (COLCIENCIAS) (Called 647 of 2014). The authors would like to thank COLCIENCIAS for funding. This work is framed at the "Contrato de acceso a recursos genéticos y productos derivados del Ministerio del Medio Ambiente y Desarrollo Sostenible de Colombia N $^{\circ} 5$ and N 159 ". Special thanks to the Enzymatic Biotechnology (Universidad Complutense de Madrid) and PROBIOM (Universidad Nacional de Colombia) groups for all their support in this work.

\section{REFERENCES}

Ashby, R. D., Solaiman, D. K. Y., Strahan, G. D., Levine, A. C., \& Nomura, C. T. 2015. Methanol-induced chain termination in poly(3-hydroxybutyrate) biopolymers: Molecular weight control. International Journal of Biological Macromolecules 74, 195-201.

Aziz, R. K., Bartels, D., Best, A. A., DeJongh, M., Disz, T., Edwards, R. A., Formsma, K., Gerdes, S., Glass, E. M., Kubal, M., Meyer, F., Olsen, G.J., Olson, R., Osterman, A. L., Overbeek, R. A., McNeil, L. K., Paarmann, D., Paczian, T., Parrello, B., Pusch, G. D., Reich, C., Stevens, R., Vassieva, O., Vonstein, V., Wilke, A., \& Zagnitko, O. 2008. The RAST Server: Rapid Annotations using Subsystems Technology. BMC Genomics 9(1): 75.

Balakrishna Pillai, A., Jaya Kumar, A., Thulasi, K., \& Harikrishnan, K. 2016. Production of short chain length polyhydroxyalkanoates by Bacillus megaterium PHB29 from starch feed stock. International Journal of Current Microbiology and Applied Sciences 5(7): 816-823.

Bhuwal, A. K., Singh, G., Aggarwal, N. K., Goyal, V., \& Yadav, A. 2014. Poly- $\beta$-hydroxybutyrate production and management of cardboard industry effluent by new Bacillus sp. NA10. Bioresources and Bioprocessing 1(1): 9.

Campos, M. I., Figueiredo, T. V. B., Sousa, L. S., \& Druzian, J. I. 2014. The influence of crude glycerin and nitrogen concentrations on the production of PHA by Cupriavidus necator using a response surface methodology and its characterizations. Industrial Crops and Products 52: 338-346.

da Silva, G. P., Mack, M., \& Contiero, J. 2009. Glycerol: A promising and abundant carbon source for industrial microbiology. Biotechnology Advances 27(1): 30-39.

Eppinger, M., Bunk, B., Johns, M. A., Edirisinghe, J. N., Kutumbaka, K. K., Koenig, S. S. K., Creasy, H. H., Rosovitz, M. J., Riley, D. R., Daugherty, S., Martin, M., Elbourne, L. D. H., Paulsen, I., Biedendieck, R., Braun, C., Grayburn, S., Dhingra, S., Lukyanchuk, V., Ball, B., Ul- 
Qamar, R., Seibel, J., Bremer, E., Jahn, D., Ravel, J., \& Vary, P.S. 2011. Genome sequences of the biotechnologically important Bacillus megaterium strains QM B1551 and DSM319. Journal of Bacteriology 193(16): 4199-4213.

Grage, K., McDermott, P., \& Rehm, B. H. A. 2017. Engineering Bacillus megaterium for production of functional intracellular materials. Microbial Cell Factories 16(1): 1-12.

Hori, K., Kaneko, M., Tanji, Y., Xing, X. H., \& Unno, H. 2002. Construction of self-disruptive Bacillus megaterium in response to substrate exhaustion for polyhydroxybutyrate production. Applied Microbiology and Biotechnology 59(2-3): 211-216.

Ibrahim, M. H. A. \& Steinbüchel, A. 2010. Zobellella denitrificans strain MW1, a newly isolated bacterium suitable for poly(3hydroxybutyrate) production from glycerol. Journal of Applied Microbiology 108(1): 214-225.

Jacquel, N., Lo, C. W., Wei, Y. H., Wu, H. S., \& Wang, S. S. 2008. Isolation and purification of bacterial poly(3hydroxyalkanoates). Biochemical Engineering Journal 39(1): 1527.

Johnson, S. L., Daligault, H. E., Davenport, K. W., Jaissle, J., Frey, K. G., Ladner, J. T., Broomall, M., Bishop-Lilly, K. A., Bruce, D. C., Gibbons, H. S., Coyne, S. R., Lo C. C., Meincke, L., Munk, A. C., Koroleva, G. I., Rosenzweig, C. N., Palacios, G. F., Redden, C. L., Minogue, T. D., Chain, P. S. 2015. Complete genome sequences for 35 biothreat assay-relevant Bacillus species. Genome Announcements 3(2): $10-11$.

Kalia, V. C., Prakash, J., \& Koul, S. 2016. Biorefinery for glycerol rich biodiesel industry waste. Indian Journal of Microbiology 56(2): 113-125.

Kawata, Y. \& Aiba, S. 2010. Poly(3-hydroxybutyrate) production by isolated Halomonas sp. KM-1 using waste glycerol. Bioscience, Biotechnology, and Biochemistry 74(1): 175-177.

Kim, B. S., Lee, S. C., Lee, S. Y., Chang, H. N., Chang, Y. K., \& Woo, S. I. 1994. Production of poly(3-hydroxybutyric acid) by fed-batch culture of Alcaligenes eutrophus with glucose concentration control. Biotechnology and Bioengineering.

Koller, M., Maršálek, L., de Sousa Dias, M. M., \& Braunegg, G. 2016. Producing microbial polyhydroxyalkanoate (PHA) biopolyesters in a sustainable manner. New Biotechnology 37: 24-38.

Kocharin, K., Chen, Y., Siewers, V., \& Nielsen, J. 2012. Engineering of acetyl-CoA metabolism for the improved production of polyhydroxybutyrate in Saccharomyces cerevisiae. AMB Express 2(1): 52.

Koller, M., Maršálek, L., de Sousa Dias, M. M., \& Braunegg, G. 2016. Producing microbial polyhydroxyalkanoate (PHA) biopolyesters in a sustainable manner. New Biotechnology 37: 24-38.

Kumar, P., Patel, S. K. S., Lee, J. K., \& Kalia, V. C. 2013. Extending the limits of Bacillus for novel biotechnological applications. Biotechnology Advances 31(8): 1543-1561.

Lindgren, V. \& Rutberg, L. 1974. Glycerol metabolism in Bacillus subtilis: gene-enzyme relationships. Journal of Bacteriology 119(2): 431-442.

Liu, L., Li, Y., Zhang, J., Zou, W., Zhou, Z., Liu, J., Li, X., Wang, L., \& Chen, J. 2011. complete genome sequence of the industrial strain Bacillus megaterium WSH-002. Journal of Bacteriology 193(22): 6389-6390.

Lopar, M., Špoljarić, I. V., Cepanec, N., Koller, M., Braunegg, G., \& Horvat, P. 2014. Study of metabolic network of Cupriavidus necator DSM 545 growing on glycerol by applying elementary flux modes and yield space analysis. Journal of Industrial Microbiology and Biotechnology 41(6): 913-930.

López, J. A., Naranjo, J. M., Higuita, J. C., Cubitto, M. A., Cardona, C. A., \& Villar, M. A. 2012. Biosynthesis of PHB from a new isolated Bacillus megaterium strain: Outlook on future developments with endospore forming bacteria. Biotechnology and Bioprocess Engineering 17(2): 250-258.

Magdouli, S., Brar, S. K., Blais, J. F., and Tyagi, R. D. 2015. How to direct the fatty acid biosynthesis towards polyhydroxyalkanoates production? Biomass and Bioenergy 74 : 268-279.

Medema, M. H., Blin, K., Cimermancic, P., De Jager, V., Zakrzewski, P., Fischbach, M. A., Weber, T., Takano, E., \& Breitling, R. 2011. AntiSMASH: Rapid identification, annotation and analysis of secondary metabolite biosynthesis gene clusters in bacterial and fungal genome sequences. Nucleic Acids Research 39: 339-346.

Meng, D.-C., Shen, R., Yao, H., Chen, J.-C., Wu, Q., \& Chen, G.Q. 2014. Engineering the diversity of polyesters. Current Opinion in Biotechnology 29(1): 24-33.

Mohapatra, S., Maity, S., Dash, H. R., Das, S., Pattnaik, S., Rath, C. C., \& Samantaray, D. 2017. Bacillus and biopolymer: Prospects and challenges. Biochemistry and Biophysics Reports 12: 206-213.

Moreno, P., Yañez, C., Cardozo, N. S. M., Escalante, H., Combariza, M. Y., \& Guzman, C. 2015. Influence of nutritional and physicochemical variables on PHB production from raw glycerol obtained from a Colombian biodiesel plant by a wild-type Bacillus megaterium strain. New Biotechnology 32(6): 682-689.

Możejko-Ciesielska, J. \& Kiewisz, R. 2016. Bacterial polyhydroxyalkanoates: Still fabulous? Microbiological Research 192(2016): 271-282.

Nikel, P. I., Pettinari, M. J., Galvagno, M. A., \& Méndez, B. S. 2008. Poly(3-hydroxybutyrate) synthesis from glycerol by a recombinant Escherichia coli arcA mutant in fed-batch microaerobic cultures. Applied Microbiology and Biotechnology 77(6): 1337-1343.

Okwuobi, P. N. \& Ogunjobi, A. A. 2013. Production and analysis of polyhydroxyalkanoate (PHA) by Bacillus megaterium using pure carbon substrates. World Applied Sciences Journal 28(9): 1336-1340.

Pappalardo, F., Fragalà, M., Mineo, P. G., Damigella, A., Catara, A. F., Palmeri, R., \& Rescifina, A. 2014. Production of filmable medium-chain-length polyhydroxyalkanoates produced from glycerol by Pseudomonas mediterranea. International Journal of Biological Macromolecules 65: 89-96.

Porras, M. A., Vitale, C., Villar, M. A., \& Cubitto, M. A. 2017. Bioconversion of glycerol to poly(HB-co-HV) copolymer in an inexpensive medium by a Bacillus megaterium strain isolated from marine sediments. Journal of Environmental Chemical Engineering 5(1): 1-9.

Povolo, S., Basaglia, M., Fontana, F., Morelli, A., \& Casella, S. 2015. Poly(hydroxyalkanoate) production by Cupriavidus necator from fatty waste can be enhanced by phaZ1 inactivation. Chemical and Biochemical Engineering Quarterly Journal 29(2): 67-74.

Povolo, S., Toffano, P., Basaglia, M., \& Casella, S. 2010. Polyhydroxyalkanoates production by engineered Cupriavidus necator from waste material containing lactose. Bioresource Technology 101(20): 7902-7907.

Pradhan, S., Dikshit, P. K., \& Moholkar, V. S. 2018. Production, ultrasonic extraction, and characterization of poly (3hydroxybutyrate) (PHB) using Bacillus megaterium and Cupriavidus necator. Polymers for Advanced Technologies 29(8): 2392-2400.

Reddy, C. S. K., Ghai, R., Rashmi, \& Kalia, V. C. 2003. Polyhydroxyalkanoates: An overview. Bioresource Technology 87(2): 137-146.

Reddy, S. V., Thirumala, M., \& Mahmood, S. K. 2009. A novel Bacillus sp. accumulating poly (3-hydroxybutyrate-co-3hydroxyvalerate) from a single carbon substrate. Journal of Industrial Microbiology \& Biotechnology 36(6): 837-843. 
Rodríguez-Contreras, A., Koller, M., Miranda-de Sousa Dias, M., Calafell-Monfort, M., Braunegg, G., \& Marqués-Calvo, M. S. 2015. Influence of glycerol on poly(3-hydroxybutyrate) production by Cupriavidus necator and Burkholderia sacchari. Biochemical Engineering Journal 94: 50-57.

Ruzheinikov, S. N., Burke, J., Sedelnikova, S., Baker, P.J., Taylor, R., Bullough, P. A., Muir, N. M., Gore M. G., \& Rice D. W. 2001. Glycerol dehydrogenase: structure, specificity, and mechanism of a family III polyol dehydrogenase. Structure 9(9): 789-802.

Sánchez, S. A., Marín, M. A., Mora, A. L., \& Yepes, M. del S. 2012. Identification of polyhydroxyalkanoate-producing bacteria in soils contaminated with fique wastes. Revista Colombiana de Biotecnología 14(2): 89-100.

Sathiyanarayanan, G., Saibaba, G., Seghal Kiran, G., \& Selvin, J. 2013. A statistical approach for optimization of polyhydroxybutyrate production by marine Bacillus subtilis MSBN17. International Journal of Biological Macromolecules 59: 170-177.

Singh, M., Kumar, P., Ray, S., \& Kalia, V. C. 2015. Challenges and opportunities for customizing polyhydroxyalkanoates. Indian Journal of Microbiology 55(3): 235-249.

Stewart, I., Schluter, P. J., \& Shaw, G. R. 2006. Cyanobacterial lipopolysaccharides and human health - A review. Environmental Health: A Global Access Science Source 5: 1-23.

Teeka, J., Imai, T., Reungsang, A., Cheng, X., Yuliani, E., Thiantanankul, J., Poomipuk, N., Yamaguchi, J., Jeenanong, A., Higuchi, T., Yamamoto, K., \& Sekine, M. 2012. Characterization of polyhydroxyalkanoates (PHAs) biosynthesis by isolated Novosphingobium sp. THA_AIK7 using crude glycerol. Journal of Industrial Microbiology \& Biotechnology 39(5): 749-758.

Yachdav, G., Kloppmann, E., Kajan, L., Hecht, M., Goldberg, T., Hamp, T., Hönigschmid, P., Schafferhans, A., Roos, M., Bernhofer, M., Richter, L., Ashkenazy, H., Punta, M., Schlessinger, A., Bromberg, Y., Schneider, R., Vriend, G., Sander, C., Ben-Tal, N., \& Rost, B. 2014. PredictProtein-an open resource for online prediction of protein structural and functional features. Nucleic Acids Research 42: W337W343.

Zhu, C., Chiu, S., Nakas, J. P., \& Nomura, C. T. 2013. Bioplastics from waste glycerol derived from biodiesel industry. Journal of Applied Polymer Science 130(1): 1-13. 